\title{
IMPLEMENTASI GOOD GOVERNANCE DALAM PENYELENGGARAAN PEMERINTAHAN DAERAH DI KOTA BUKITTINGGI
}

\author{
S A R I \\ Magister Ilmu Hukum Fakultas Hukum Universitas Jenderal Soedirman
}

\begin{abstract}
The implementation of regional autonomy with the principle of decentralization have a positive impact in the context of equity and increased development in the area which is a means to enable local people to be able to optimize the ability to prosper in their lives. This research used normative methode which used law statute approach and analutycal approach. Based on the results of research are Implementation of good governance in local government activity in Bukittinggi run quite effectively in Parliament as an institution as well as the local legislative offices as the technical implementation unit area. Constraints that affect the implementation of good governance in local government activity in Bukittinggi are: In offices, constraints experienced such quality and quantity of human resources, facilities and infrastructure, local regulations are not yet on the whole set of public service performance; In parliament that institutional constraints, human resource constraints, budget constraints, and constraint rules which all the constraints associated with the function of Parliament itself that not enough achievement of the performance by legislators.
\end{abstract}

Keyword: Implementation, Good Governance, Bukittinggi Government

\begin{abstract}
ABSTRAK
Penyelenggaraan otonomi daerah dengan asas desentralisasi memberikan dampak yang positif dalam rangka pemerataan dan peningkatan pembangunan di daerah. Ide desentralisasi muncul sebagai dampak adanya tuntutan masyarakat akan perlunya percepatan pelayanan publik yang harus dilakukan oleh pemerintah kepada masyarakat. Data yang telah disajikan dalam bentuk teks naratif, yaitu suatu uraian dan penjabaran yang tersusun secara logis, konsisten, rasional dan sistematis. Metode penelitian yang digunakan adalah yuridis normatif dengan metode pendekatan undang-undang dan analitis. Hasil penelitian menunjukkan bahwa Implementasi Good Governance dalam Penyelenggaraan Pemerintahan Daerah di Kota Bukittinggi berjalan cukup efektif pada DPRD selaku lembaga legislatif daerah serta dinas-dinas selaku unit pelaksana teknis daerah. Kendala yang mempengaruhi Implementasi Good Governance dalam Penyelenggaraan Pemerintahan Daerah di Kota Bukittinggi diantaranya kualitas dan kuantitas dari SDM, sarana dan prasarana, perda-perda yang belum secara keseluruhan mengatur tentang kinerja pelayanan publik. Pada DPRD yaitu kendala kelembagaan, kendala SDM, kendala anggaran, dan kendala peraturan yang kesemuanya kendala tersebut berkaitan dengan fungsi DPRD itu sendiri yang memunculkan ketidakmasimalan pencapaian kinerja oleh anggota DPRD.
\end{abstract}

Kata Kunci: Implementasi, Good Governance, Pemerintahan Bukittinggi

\section{PENDAHULUAN}

Indonesia sebagai negara kesatuan

menganut asas desentralisasi dalam menyelenggarakan pemerintah dengan memberikan kesempatan dan keleluasan kepada daerah untuk menyelenggarakan otonomi daerah. Ketentuan
Undang-Undang Dasar Negara Republik Indonesia 1945, Pasal 18 ayat (1) menyebutkan bahwa Negara Kesatuan Republik Indonesia dibagi atas daerah-daerah provinsi dan daerah provinsi dibagi atas kabupaten dan kota, yang tiap-tiap provinsi, 
kabupaten, dan kota mempunyai pemerintahan daerah, yang diatur oleh Undang-undang.

Undang-undang Nomor 32 tahun 2004 sebagaimana yang telah diganti dengan UndangUndang Nomor 23 Tahun 2014 tentang Pemerintahan Daerah dalam Pasal 1 angka 2 disebutkan bahwa Pemerintahan daerah adalah penyelenggaraan urusan pemerintahan oleh pemerintah daerah dan DPRD menurut asas otonomi dan tugas pembantuan dengan prinsip otonomi seluasluasnya dalam sistem dan prinsip Negara Kesatuan Republik Indonesia sebagaimana dimaksud dalam Undang-Undang Dasar Negara Republik Indonesia Tahun 1945. Sehubungan dengan itu, penyerahan kekuasaan dari rakyat pada negara terbagi 2 (dua): (1) Pemerintah (eksekutif) yang diserahi kekuasaan untuk melaksanakan pengaturan berbagai kebutuhan masyarakat; (2) Lembaga perwakilan rakyat (legislatif) yaitu lembaga yang berwenang dalam hal merumuskan dan membuat aturan untuk dilaksanakan oleh pemerintah serta melakukan pengawasan atas tindakantindakan pemerintah.

Penyelenggaraan otonomi daerah dengan asas desentralisasi memberikan dampak yang positif dalam rangka pemerataan dan peningkatan pembangunan di daerah yang merupakan sarana untuk memampukan masyarakat daerah untuk dapat mengoptimalkan kemampuan diri dalam mensejahterakan kehidupan mereka. Ide desentralisasi muncul sebagai dampak adanya tuntutan masyarakat akan perlunya percepatan pelayanan publik yang harus dilakukan oleh pemerintah kepada masyarakat. Keberhasilan pelaksanaan fungsi pelayanan publik oleh pemerintah daerah akan mempengaruhi terwujudnya konsep negara kesejahteraan (welfarestaat) sesuai dengan yang diamanatkan dalam Pembukaan UUD 1945 alinea ke -IV, yaitu:

“.... Melindungi segenap bangsa Indonesia dan seluruh tumpah darah Indonesia dan untuk memajukan kesejahteraan umum, mencerdaskan kehidupan bangsa, dan ikut melaksanakan ketertiban dunia yang berdasarkan kemerdekaan, perdamaian abadi, dan keadilan sosial."

Sehubungan dengan hal tersebut, sebuah konsep tata kepemerintahan yang baik (Good Governance), sekarang menjadi salah satu kata kunci dalam wacana untuk membenahi sistem penyelenggaraan pemerintahan di Indonesia. United Nations Development Programme selanjutnya disingkat (UNDP), mendefinisikan kepemerintahan

(Governance) sebagai pelaksanaan kewenangan atau kekuasaan dibidang ekonomi, politik dan administratif untuk mengelola berbagai urusan negara pada setiap tingkatannya dan merupakan instrumen kebijakan negara untuk mendorong terciptanya kondisi kesejahteraan integritas dan kohesivitas sosial dalam masyarakat. ${ }^{1}$

Good Governance di Indonesia, dapat didefinisikan sebagai praktek penyelenggaraan pemerintahan yang demokratis dengan kemampuan mengelola berbagai sumberdaya sosial dan ekonomi dengan baik untuk kepentingan rakyat Indonesia berdasarkan asas musyawarah dan mufakat. Di dalam rumusan Pasal 3 UU. Nomor 28 Tahun 1999 tentang Penyelenggaraan Negara Pelayanan Public.UGM Press.Yogyakarta. 2006.hlm. 78. 
Yang Bersih dan Bebas Korupsi Kolusi dan Nepotisme, telah secara tegas dan limitatif diatur prinsip-prinsip kepemerintahan yang baik atau lebih dikenal dengan istilah good governance. Prinsip-prinsip good governance dalam praktek penyelenggaraan Negara dituangkan dalam 7 (tujuh) asas-asas umum penyelenggaraan negara sebagaimana dimaksud dalam UU Nomor 28 Tahun 1999 tentang Penyelenggaraan Negara Yang Bersih dan Bebas Korupsi Kolusi dan Nepotisme.

Asas tersebut yakni: (1) Asas kepastian hukum, adalah asas dalam negara hukum yang mengutamakan landasan peraturan perundangundangan, kepatutan, dan keadilan dalam setiap kebijakan penyelenggaraan negara; (2) Asas tertib penyelenggaraan negara adalah asas yang menjadi landasan keteraturan, keserasian, dan keseimbangan dalam pengendalian penyelenggaraan negara; (3) Asas kepentingan umum adalah asas yang mendahulukan kepentingan umum dengan cara yang aspiratif, akomodatif, dan selektif; (4) Asas keterbukaan adalah asas yang membuka diri terhadap hak masyarakat untuk memperoleh informasi yang benar, jujur, dan tidak diskriminatif tentang penyelenggaraan negara dengan tetap memperhatikan perlindungan atas hak asasi pribadi, golongan, dan rahsia negara; (5) Asas proporsionalitas adalah asas yang mengutamakan keseimbangan antara hak dan kewajiban penyelenggaraan negara; (6) Asas profesionalisme adalah asas yang mengutamakan keahlian yang berlandaskan kode etik dan ketentuan peraturan perundang-undangan yang berlaku. (7)
Asas akuntabilitas adalah asas yang menentukan bahwa setiap kegiatan dan hasil akhir dari kegiatan penyelenggaraan negara harus dapat dipertanggungjawabkan kepada masyarakat atau rakyat sebagai pemegang kedaulatan tertinggi negara sesuai dengan ketentuan peraturan perundang-undangan yang berlaku.

Asas-asas Umum Penyelenggaraan Pemerintahan yang Baik yang dijelaskan diatas berlaku untuk semua tingkatan pemerintahan baik pemerintah pusat maupun pemerintahan daerah. Dalam penyelenggaraan pemerintahan otonomi daerah, pemerintah daerah dituntut untuk menerapkan prinsip-prinsip yang dituangkan dalam asas-asas tersebut di atas dalam kepemerintahan untuk menjadi salah satu ukuran keberhasilan kinerja pemerintahan daerah khususnya dalam pelayanan publik.

Unsur - unsur dari Good Governance adalah negara, sektor swasta, dan masyarakat. Jika dilihat dari ketiga domain tersebut, negara menjadi domain yang paling penting dalam mewujudkan Good Governance, karena fungsi pengaturan yang memfasilitasi domain sektor usaha swasta dan masyarakat, serta fungsi administratif penyelenggaraan pemerintahan juga melekat pada domain ini. ${ }^{2}$ Sehubungan dengan itu, peneliti menekankan penelitian ini pada sektor negara (pemerintahan daerah) yaitu eksekutif dan legislatif di Pemerintahan Kota Bukittinggi melalui kebijakan-kebijakan yang dibuat oleh kepala daerah dalam mengakomodir sektor swasta dan masyarakat dalam meningkatkan pelayanan publik, dan bagaimana dinas-dinas daerah sebagai

\footnotetext{
2 Sedarmayanti, Good Governance (Kepemerintahan Yang
} Baik), Mandar Maju, Bandung, 2012, hlm 8. 
pelaksana teknis kebijakan pelayanan publik berupaya untuk meningkatkan pelayanan publik berdasarkan implementasi prinsip-prinsip Good Governance.

Bukittinggi sebagai salah satu kota di Provinsi Sumatera Barat dan juga sebagai lbu Kota Pemerintahan Darurat Republik Indonesia ( PDRI ) pada zaman perjuangan Kemerdekaan Republik Indonesia, memiliki potensi yang besar dalam bidang perdagangan dan jasa, pertanian, dan pariwisata. Bidang perdagangan dan jasa ditetapkan sebagai potensi unggulan daerah. Sektor perdagangan dan jasa merupakan sektor penyumbang utama bagi pendapatan Kota Bukittinggi sebesar $50 \%$. Selain itu, kota ini juga berpotensi di bidang industri, wisata perdagangan dan jasa, wisata konferensi dan peristirahatan yang menyumbang Pendapatan Asli Daerah (PAD) Bukittinggi yaitu berkisar antara 30-40 \%. ${ }^{3}$

Perkembangan tersebut menuntut pemerintah daerah Kota Bukittinggi untuk dapat menerapkan pemerintahan yang berorientasi kepada budaya, etos kerja, pencapaian hasil, dan pertanggungjawaban untuk mewujudkan Good Governance. Dari uraian diatas, maka penulis tertarik untuk meneliti dan menganalisis implementasi Good Governance di Kota Bukittinggi dalam mewujudkan penyelenggaraan otonomi daerah untuk mewujudkan Good Governance dalam Local Governance. Dalam hubungan ini, kata prinsip mempunyai makna yang sama dengan asas, karena asas dan/atau prinsip pada hakekatnya

\footnotetext{
${ }^{3}$ Dikuti dari http://www.bukittinggikota.go.id/diakses tanggal 7 Maret 2014 pukul 15.30 WIB.
}

merupakan awal suatu kebenaran yang menjadi pokok dasar tujuan berpikir, berpendapat, dan bertindak.

\section{METODE PENELITIAN}

Metode pendekatan yang dipakai pendekatan undang-undang (statute approach). Metode pendekatan lainnya yang digunakan adalah pendekatan Analitis (Analytical Approach). ${ }^{4}$ Tipe penelitian yang digunakan adalah penelitian yuridis normatif. Sumber data yang digunakan adalah menggunakan data sekunder. Data-data yang diperoleh dianalisa dengan menggunakan metode kualitatif dengan menjabarkan dan memberikan interpretasi terhadap data yang diperoleh berdasarkan norma-norma hukum, teoriteori dan doktrin yang berlaku dihubungkan dengan pokok permasalahan. ${ }^{5}$

\section{PEMBAHASAN}

Implementasi Good Governance dalam penyelenggaraan pemerintahan daerah di Kota Bukittinggi

Good Governance di Indonesia, dapat didefinisikan sebagai praktek penyelenggaraan pemerintahan yang demokratis dengan kemampuan mengelola berbagai sumberdaya sosial dan ekonomi dengan baik untuk kepentingan rakyat Indonesia berdasarkan asas musyawarah dan mufakat. Di dalam rumusan Pasal 3 UU. Nomor 28 Tahun 1999, telah secara tegas dan limitatif diatur prinsip-prinsip kepemerintahan yang baik atau

\footnotetext{
4 Johnny Ibrahim, 2011, Teori dan Metodologi Penelitian Hukum Normatif, Cetakan Keempat, Bayumedia Publishing, Malang, hlm.310.

${ }^{5}$ Soejono Soekanto, 1988, Pengantar Penelitian Hukum, UI Press, Jakarta, hlm.12
} 
lebih dikenal dengan istilah good governance. Prinsip-prinsip good governance dalam praktek penyelenggaraan Negara dituangkan dalam 7 (tujuh) asas-asas umum penyelenggaraan negara sebagaimana dimaksud dalam UU Nomor 28 Tahun 1999 tentang Penyelenggaraan Negara Yang Bersih dan Bebas Korupsi Kolusi dan Nepotisme.

Asas-asas Umum Penyelenggaraan Pemerintahan yang Baik yang dijelaskan diatas berlaku untuk semua tingkatan pemerintahan baik pemerintah pusat maupun pemerintahan daerah. Dalam penyelenggaraan pemerintahan otonomi daerah, pemerintah daerah dituntut untuk menerapkan prinsip-prinsip yang dituangkan dalam asas-asas tersebut diatas dalam kepemerintahan untuk menjadi salah satu ukuran keberhasilan kinerja pemerintahan daerah khususnya dalam pelayanan publik.

\section{Asas Kepastian Hukum}

Adalah asas dalam negara hukum yang mengutamakan lan-dasan peraturan perundangundangan, kepatutan, dan keadilan dalam setiap kebijakan penye-lenggaraan negara, dalam pelaksanaan kebijakan oleh instansi-instansi tersebut, nampaknya sudah sesuai dengan peraturan perundang-undangan yang berlaku dan masyarakat setempat pun telah mengetahui prosedur-prosedur apa yang harus mereka lakukan dan syarat-syarat yang harus dipenuhi dalam mengurus berbagai kepentingan mereka pada instansi-instansi tersebut diatas. Sosialisasi yang dilakukan pemda setempat cukup maksimal dilakukan kepada masyarakat mengenai ketentuan-ketentuan yang harus dipatuhi dalam melakukan berbagai kepentingan pada instansiinstansi tersebut.

\section{Asas Tertib Penyelenggaraan Negara}

Adalah asas yang menjadi landasan keteraturan, keserasian, dan keseimbangan dalam pengendalian penyelenggaraan negara, pelaksanaan asas ini dapat dilihat dari pengambilan kebijakan oleh setiap instansi melalui perda yang mengatur pembentukan instansi tersebut. Menurut Perda Nomor 11 Tahun 2008 tentang Pembentukan Organisasi dan Tata Kerja Lembaga Teknis Daerah Kota Bukittinggi BPPTPM Kota Bukittinggi mempunyai tugas dalam melaksanakan koordinasi dan menyelenggarakan pelayanan administrasi di bidang perzinan secara terpadu dengan prinsip koordinasi, integrasi, sinkronisasi, simplikasi, keamanan, dan kepastian.

\section{Asas Kepentingan Umum}

Adalah asas yang mendahulukan kesejahteraan umum dengan cara yang aspiratif, akomodatif dan kolektif. Penerapan asas ini pada DPRD terlihat dari fungsi-fungsi DPRD, yaitu fungsi legislatifnya serta produk-produk hukum yang dihasilkan bersama pemerintah daerah yang bertujuan untuk kepentingan masyarakat. Fungsi legislasi dari DPRD ini merupakan suatu proses untuk mengakomodasi berbagai kepentingan stakeholder termasuk kepentingan masyarakat yang menjadi tujuan utama dalam pembentukan perda. Fungsi legislasi ini merupakan fungsi yang menentukan arah dan kebijakan yang berbasis pada rakyat dan sebagai pengemban amanah 
rakyat mempunyai kewenangan untuk memperjuangkan rakyat yang diwakili.

Penerapan asas ini pada Diskoperindag, Disdukcapil, dan BPPTPM dapat dilihat dari tujuan pembentukan dinas-dinas itu sendiri yang dijabarkan dalan Rencana Strategis dan Rencana Kerja pada masing-masing dinas. Pada Diskoperindag, dalam Renstra 2010-2015 disebutkan bahwa penjabaran Renstra Diskoperindag Kota Bukittinggi merupakan upaya peningkatan kesejahteraan penduduk melalui program kerja Diskoperindag Kota Bukittinggi yang telah mengacu pada program strategis Kota Bukittinggi sebagai Kota Pariwisata, Kota Perdagangan, Kota Pendidikan, dan Kota Pelayanan Kesehatan. Salah satu program strategis kota tersebut (Kota Perdagangan) merupakan tanggungjawab langsung (Tupoksi) Diskoperindag Kota Bukittinggi. Pilihan strategis pembangunan Kota Bukittinggi sebagai Kota Perdagangan sangat sesuai dengan potensi yang dimiliki Kota Bukittinggi dan daerah yang berbatasan langsung serta daerah sekitar lainnya. Aktivitas perdagangan tersebut sangat didukung oleh pembangunan sektoral industri dan koperasi yang sekaligus menjadi tugas/tanggungjawab Diskoperindag Kota Bukittinggi.

\section{Asas Keterbukaan}

Adalah asas yang membuka diri terhadap hak masyarakat untuk memperoleh informasi yang benar, jujur, dan tidak diskriminatif tentang penyelenggaraan negara dengan tetap memperhatikan perlindungan atas hak asasi pribadi, golongan, dan rahasia negara. Asas ini sekarang ditegaskan dalam UU No 14 tahun 2008 tentang Keterbukaan Informasi Publik.
Indikator kinerja program DPRD sebagai perwakilan rakyat di daerah, dalam menerapkan asas ini dengan melakukan sosialisasi peraturan perundang-undangan kepada masyarakat dengan output masyarakat memahami dan mengerti tentang peraturan, publikasi atau sosialisasi produk kebijakan dan kegiatan DPRD Kota Bukittinggi, promosi melalui media massa, profil dan dokumentasi kegiatan DPRD.

Penerapan asas ini pada Diskoperindag Kota Bukittinggi terlihat dari tujuan, sasaran strategis, serta kinerja pembangunan oleh Diskoperindag antara lain: (1) Sosialisasi UU Nomor 20 Tahun 2008 tentang UMKM yang meningkatkan pertumbuhan 24 koperasi/ UMKM; (2) Penyebarluasan informasi KUMKM melalui media massa; (3) Peningkatan pengetahuan masyarakat tentang ketentuan maupun kualitas barang beredar; (4) Peningkatan pengetahuan pengurus dan pengelola koperasi tentang manajemen dan perkoperasian; (5) Peningkatan pengetahuan dan keterampilan pengusaha mikro tentang bisnis dan kehidupan berkelompok serta berkembangnya organisasi wadah pengusaha mikro yang solid.

Dari indikator diatas, terdapat keterbukaan informasi pada publik atau masayarakat dalam kebijakan yang dibuat oleh Diskoperindag, diantaranya penyebarluasan informasi mengenai KUMKM yang berimplikasi pada pertumbuhan koperasi dan UMKM yang ada di Kota Bukittinggi, serta pembinaan pengetahuan tentang bisnis dan koperasi pada pengurus dan pengusaha agar lebih kreatif mengembangkan usahanya yang dapat meningkatkan pendapatan daerah dari sektor perdagangan. 
Pada Disdukcapil, penerapan asas ini dilakukan dengan program kerja antara lain sosialisasi kebijakan kependudukan, melakukan sosialisasi akan arti pentingnya sistem administrasi kependudukan dan catatan sipil kepada masyarakat dalam Kota Bukittinggi, meningkatkan pemahaman / kesadaran masyarakat tentang arti, manfaat dan pentingnya dokumen kependudukan, memberikan pemenuhan hak-hak administratif, seperti pelayanan publik yang profesional, meningkatkan kesadaran akan arti pentingnya administrasi kependudukan sehingga masyarakat mengetahui akan kewajibannya dan ikut berperan serta dalam pelaksanaan administrasi kependudukan, dan mendukung perumusan kebijakan dan perencanaan pembangunan secara nasional, regional dan lokal. ${ }^{6}$

Dengan program kerja diatas, masyarakat mendapatkan informasi dan pengetahuan tentang pentingnya administrasi kependudukan yang diarahkan untuk mempercepat terwujudnya kesejahteraan masyarakat melalui peningkatan pelayanan, pemberdayaan dan peran serta masyarakat.

Pada BPPTPM, untuk memaksimalkan pengetahuan masyarakat tentang tata cara mendapatkan pelayanan perizinan dan penanaman modal, maka indikator kerja yang telah dilakukan oleh BPPTPM antara lain:

1. Penyusunan draf ranperda pedoman pelayanan perizinan, dengan tujuan memberikan kepastian hukum bagi masyarakat tentang kebijakan yang akan diambil oleh BPPTPM dalam meningkatkan pelayanan publik terhadap masyarakat dalam bidangnya sesuai dengan peraturan perundangundangan yang berlaku dan tidak berdasarkan kesewenang-wenangan belaka.

2. Penyusunan buku SOP pelayanan perizinan, pembuatan profil BPPTPM, dan pembuatan buku saku pelayanan yang kesemuanya dimaksudkan untuk memberikan informasi kepada masyarakat tentang tatacara yang harus dipatuhi dalam mengurus suatu perizinan atau kepentingankepentingan yang terkait dengan bidangbidang di BPPTPM.

3. Verifikasi dan penyelesaian pengaduan masyarakat, dalam hal ini BPPTPM melalui pegawai dari masing-masing bidang menghimpun berbagai pengaduan dari masyarakat terkait masalah-masalah seputar pelayanan yang diberikan oleh BPPTPM dan memberikan penyelesaian terhadap pengaduan tersebut.

4. Operasional pelayanan perizinan keliling, merupakan terobosan baru yang dilakukan oleh BPPTPM dalam meningkatkan kepuasan dan memberikan kemudahan kepada masyarakat tidak hanya dengan menerapkan pelayanan terpadu satu pintu, tetapi juga memudahkan masyarakat yang mempunyai mobilitas yang tinggi dalam mengurus perizinan tanpa harus datang ke kantor yang ke depannya bertujuan untuk meningkatkan pembangunan di Kota Bukittinggi dengan menerapkan kemudahan dalam pengurusan perizinan serta penana-

\footnotetext{
${ }^{6}$ Rencana Kerja Disdukcapil Tahun 2013, hlm 16-17.
} 
man modal oleh para stakeholder yang berujung pada peningkatan pemasukan bagi daerah.

\section{Asas Proporsionalitas}

Adalah asas yang mengutamakan keseimbangan antara hak dan kewajiban penyelenggara negara, pada DPRD asas ini terkait dengan kualitas dari perda-perda yang dihasilkan oleh DPRD apakah sudah sesuai dengan harapan masyarakat daerah, sudah menampung dan memenuhi aspirasi masyarakat daerah, dan bertujuan untuk kepentingan umum, bukan untuk kepentingan golongan atau, parpol, atau pribadi. Sebagaimana disebutkan dalam hasil penelitian tesis ini tentang hak dan kewajiban DPRD, dapat dilihat penerapan asas ini melalui perda-perda yang dihasilkan antara lain perda tentang penyelenggaraan administrasi kependudukan, yaitu Perda Nomor 01 Tahun 2011. Perda ini mengantarkan Kota Bukittinggi sebagai Pilot Project dalam keberhasilan percepatan penerapan e-KTP yang diberikan penghargaan langsung oleh Menteri Dalam Negeri. Disini dapat dilihat keberhasilan dari DPRD Kota Bukittinggi dalam menjalankan kewajibannya sebagai policy maker dan pembuat peraturan perundang-undangan yang mengacu pada peningkatan pelayanan publik pada masyarakat daerah dan meningkatkan kepercayaan masyarakat sebagai wakil rakyat yang mengakomodir kepentingan umum.
Pada Diskoperindag, penerapa asas ini terdapat pada kinerja yang dihasilkan dalam meningkatkan pelayanan kepada masyarakat di bidang koperasi, perindustrian, dan perdagangan. Implementasi keseimbangan antara hak dan kewajiban pada Diskoperindag dilihat dari indikator kinerja yang berhasil diterapkan pada masyarakat.

Selanjutnya pada Disdukcapil, penerapan asas ini dilihat dari kebijakan yang ditetapkan oleh Disdukcapil dalam pelaksanaan kewajibannya sebagai penyelenggara administrasi kependudukan antara lain : ${ }^{7}$

1. Melaksanakan pembinaan dan pengawasan terhadap dokumen kependudukan dan pencatatan sipil;

2. Melaksanakan sosialisasi peraturan perundang-undangan bidang administrasi kependudukan dan pencatatan sipil;

3. Menyediakan sarana dan prasarana pendukung kegiatan bidang kependudukan dan pencatatan sipil;

4. Mengikut sertakan pegawai Dinas Kependudukan dan Pencatatan Sipil dalam diklat dan bimbingan teknis

5. Melaksanakan koordinasi, dan kerjasama dengan instansi pemerintah, swasta dan institusi masyarakat.

Pada BPPTPM, penerapan asas ini dilihat dari pencapaian indikator kinerja sebagai penyelenggara urusan pemerintahan daerah di bidang pelayanan perizinan dan penanaman modal yang terdapat dalam program kebijakan BPPTPM antara lain :

1. Meningkatkan kualitas sumber daya aparatur, baik dari segi teknis, maupun mental.

2. Menata kelembagaan organisasi secara efektif dan efisien dan berorientasi kepada visi.

\footnotetext{
7 Laporan Akuntabilitas Kinerja Instansi Pemerintah Disdukcapil Tahun 2013, hlm 18.
} 
3. Mengintegrasikan dan mensinkronkan program/kegiatan SKPD sesuai tugas pokok dan fungsi masing-masing untuk menunjang pencapaian visi dan misi pembangunan daerah.

\section{Asas Profesionalisme}

Adalah asas yang mengutamakan keahlian yang berdasarkan kode etik dan ketentuan peraturan perundang undangan yang berlaku. DPRD wajib menyusun kode etik. Kode etik merupakan norma-norma aturan yang merupakan kesatuan landasan etika atau filosofi dengan peraturan perilaku maupun ucapan mengenai halhal yang diwajibkan, dilarang, atau tidak patut dilakukan oleh anggota DPRD. Tujuan dari penyusunan kode etik disusun oleh DPRD bertujuan untuk menjaga martabat, kehormatan, citra, dan kredibilitas anggota DPRD dalam melaksanakan dan menjalankan tugas dan wewenangnya. Dalam kode etik ini tertera aturan dalam melaksanakan dan menjalankan tugas dan wewenangnya,tentang sikap,tata kerja, dan hubungan antar penyelenggara pemerintahan daerah dan antar anggota, serta antar anggota DPRD dengan pihak lain, termasuk juga etika dalam menyampaikan pendapat, tanggapan, jawaban, sanggahan, dan sanksi serta rehabilitasi. Semua aturan tersebut juga menjadi acuan kerja serta pedoman DPRD dalam melaksanakan trifungsi DPRD sehari-hari. ${ }^{8}$

Pada Diskoperindag, penerapan asas ini dapat dilihat dari ketentuan peraturan perundang- undangan yang mengatur tentang pelaksanaan tugas pokok dan fungsi, dari Diskoperindag dalam membuat dan melaksanakan kebijakan untuk menyelenggarakan pelayanan publik di daerah yang diatur dalam Undang-Undang Nomor 12 Tahun 2008 tentang Pembentukan Organisasi dan Tata Kerja Dinas Daerah Kota Bukittinggi pada pasal 28. Landasan hukum visi dan misi Disperindag Kota Bukittinggi terdapat dalam Peraturan Walikota Bukittinggi Nomor 13 Tahun 2010. Sedangkan untuk rencana kerja serta rencana strategis Disperindag Kota Bukittinggi disusun berdasarkan peraturan perundangundangan yang telah disebutkan dalam penerapan asas kepastian hukum diatas.

Pada Disdukpil, penerapan asas ini dapat dilihat dari ketentuan peraturan perundangundangan yang mengatur tentang pelaksanaan tugas pokok dan fungsi dari Disdukpil dalam membuat dan melaksanakan kebijakan untuk menyelenggarakan pelayanan publik di bidang administrasi kependudukan di daerah yang diatur dalam Undang-Undang Nomor 12 Tahun 2008 tentang Pembentukan Organisasi dan Tata Kerja Dinas Daerah Kota Bukittinggi pada pasal 28. Landasan hukum visi dan misi Disperindag Kota Bukittinggi terdapat dalam Peraturan Walikota Bukittinggi Nomor 13 Tahun 2010.

Pada BPPTPM sama halnya dengan 2 (dua) dinas sebelumnya, penerapan asas professional ini terdapat dalam tugas pokok dan fungsi yang diatur dalam Undang-Undang Nomor 12 Tahun 2008 tentang Pembentukan Organisasi dan Tata Kerja Dinas Daerah. Sedangkan untuk

\footnotetext{
${ }^{8}$ Profil dan Kinerja DPRD Kota Bukittinggi Periode 2009-2014, $\mathrm{hlm} .20$.
} 
rencana kerja serta rencana strategis BPPTPM Kota Bukittinggi disusun berdasarkan peraturan perundang-undangan yang telah disebutkan dalam penerapan asas kepastian hukum diatas.

\section{Asas Akuntabilitas}

Adalah asas yang menentukan bahwa setiap kegiatan dan hasil akhir dari kegiatan penyelenggaraan negara harus dapat dipertanggungjawabkan kepada masyarakat atau rakyat sebagai pemegang kedaulatan tertinggi negara sesuai dengan ketentuan peraturan perundangundangan yang berlaku.

Penerapan asas ini pada DPRD dapat dilihat dari kewajiban anggota DPRD yang diantaranya memberikan pertanggungjawaban secara moral dan politis kepada pemilih dan daerah pemilihnya. DPRD dipilih oleh masyarakat daerah dan bertanggungjawab dalam memperjuangkan aspirasi dan kepentingan masyarakat daerahnya sebagai wakil rakyat di daerah. Sesuai dengan praktek kehidupan demokrasi, keberadaan DPRD memiliki posisi sentral yang mewakili kewenangan dalam menyuarakan aspirasi masyarakat daerah, dan memberikan kontribusi dalam penetapan kebijakan politik pemerintah.

Pada Diskoperindag, merunut pada Inpres Nomor 7 Tahun 1999 yang mewajibkan setiap instansi pemerintah sebagai unsur penyelenggara urusan negara untuk mempertanggung jawabkan pelaksanaan tugas pokok dan fungsi serta kewenangan pengelolaan sumber daya dan

\footnotetext{
- Laporan Akuntabilitas Kinerja Instansi Pemerintah Diskoperindag Tahun 2013, hlm 1-2.
}

kebijakan yang dipercayakan berdasarkan perencanaan stratejik yang dirumuskan sebelumnya. memiliki laporan pertanggungjawaban.

Penyusunan Laporan Akuntabilitas Kinerja Instansi Pemerintah selanjutnya disebut LAKIP pada Diskoperindag ini bertujuan untuk mempertanggungjawabkan keberhasilan atau kegagalan pelaksanaan misi organisasi dalam mencapai tujuan-tujuan dan sasaran-sasaran dengan strategi berupa kebijakan program yang terdiri atas kegiatan-kegiatan yang telah ditetapkan Renstra 2010-2015 yang pendanaan kegiatan berasal dari APBD Kota Bukittinggi. Tujuan penyusunan LAKIP Diskoperindag Tahun 2013 secara umum adalah sebagai perwujudan akuntabilitas instansi kepada pihak-pihak yang memberi mandat dan terciptanya system pelaporan akuntabilitas yang dapat meningkatkan kepercayaan terhadap pemerintah serta meningkatkan kinerja instansi pemerintah dalam menjalankan misi. Tujuan akhir dari penyusunan LAKIP yaitu diharapkan dapat terciptanya kepemerintahan yang baik (good governance) ${ }^{9}$

Sama halnya dengan Disdukpil, penyusunan LAKIP merupakan bentuk pertanggungjawaban atas keberhasilan atau kegagalan pelaksanaan Renstra kepada pihak pemberi mandat, oleh unit kerja yang lebih rendah kepada yang lebih tinggi atau pertanggungjawaban dari bawahan kepada atasan dan sebagai tindak lanjut atau respon terhadap Instruksi Presiden Nomor 7 Tahun 1999 Tentang Akuntabilitas Kinerja Instansi Pemerintah. 
Pada BPPTPM, penerapan asas ini juga dalam bentuk LAKIP berdasarkan Instruksi Presiden Nomor 7 Tahun 1999 Tentang Akuntabilitas Kinerja Instansi Pemerintah yang bertujuan memberikan gambaran yang jelas, transparan, dan dapat dipertanggungjawabkan tentang kinerja suatu instansi pemerintah. Hasilnya diharapkan dapat membantu pimpinan dan seluruh jajaran instansi pemerintah dalam mencermati berbagai permasalahan sebagai bahan acuan dalam menyusun program di tahun berikutnya. Dengan demikian program di tahun mendatang dapat disusun lebih fokus, efektif, efisien, terukur, transparan, dan dapat dipertanggungjawabkan. ${ }^{10}$

Kendala-kendala yang mempengaruhi implementasi Good Governance dalam penyelenggaraan pemerintahan daerah di Kota Bukittinggi

Pada DPRD penerapan asas-asas yang

terdapat dalam Undang-Undang Nomor 28 Tahun 1999 tentang Penyelenggaraan negara yang Bersih dan Bebas Dari Korupsi, Kolusi, dan Nepotisme terkait tugas dan fungsi dari DPRD itu sendiri, misalnya dalam fungsi legislasi yang merupakan fungsi yang sangat penting dalam rangka mendukung pelaksanaan otonomi luas di daerah dalam pembentukan Ranperda, hambatan yang ada antara lain : ${ }^{11}$
a. Kendala Kelembagaan
b. Kendala Individual (Sumber Daya Manusia)
c. Kendala Anggaran
d. Kendala Peraturan

Pada Diskoperindag kendala yang dihadapi dalam implementasi good governance

10 Loc.cit hlm 1.

11 Buku Profil dan Kinerja DPRD Kota Bukittinggi Masa Bhakti 2009-2014, hlm 53-61. berdasarkan asas-asas tersebut diatas melalui capaian kinerjanya antara lain $:^{12}$

1. Optimalisasi kemitraan dengan sumber modal, kegagalan disebabkan adanya kebijakan baru Menteri BUMN untuk menghentikan sementara penyaluran dana PKBL (Program Kemitraan dan Bina Lingkungan) BUMN sehingga berpengaruh pada realisasi kegiatan ini.

2. Penataan kelembagaan koperasi dengan realisasi yang kurang baik yang berimplikasi dibubarkannya beberapa koperasi dengan sebab kegiatan koperasi sudah tidak berjalan dan keberadaan koperasi sudah tidak ditemukan.

3. Kurangnya jumlah personil secara kuantitas yang mendukung pelaksanaan tupoksi dan kurangnya personil yang memiliki latar belakang pendidikan dan pengalaman yang sesuai dengan kebutuhan.

4. Seringnya terjadi penggantian pengurus dan pengawas koperasi berdampak pada kualitas kehidupan koperasi.

5. Kurangnya pemahaman anggota koperasi di bidang perkoperasian berdampak pada kualitas partisipasi anggota serta kurangnya pengkaderan.

6. Rendahnya kualitas SDM UMKM kadangkala berdampak pada pola pikir UMKM dalam mengelola fasilitas permodalan yang diberikan sehingga terjadi tunggakan dalam peminjaman.

7. Tidak adanya pengusulan dari Diskoperindag terhadap Dana Alokasi Khusus bidang sarana perdagangan tahun anggaran 2013 yaitu penyediaan sarana dan prasarana pasar.

8. Tidak tersedianya lahan untuk kegiatan penyediaan sarana dan prasarana pasar sesuai Peraturan Menteri Perdagangan mengenai Petunjuk Teknis penggunaan Dana Alokasi Khusus bidang sarana perdagangan. Permasalahan ini ditindaklanjuti dengan mengirimkan telaah staf walikota Bukittinggi pada bulan Mei 2013 untuk dikembalikannya Dana Alokasi Khusus disebabkan tidak tersedianya lahan untuk penyediaan pasar di Kota Bukittinggi, tapi sampai akhir tahun tidak ada jawaban

12 Laporan Akuntabilitas,.Opcit,. hlm 61-67 
secara tertulis maupun lisan dari Kementrian Perdagangan RI.

9. Kurangnya tenaga aparatur yang ditempatkan pada subdin perdagangan. Kurangnya aparatur yang menguasai bidang perdagangan yang dari 2 seksi yang ada di bidang perdagangan.

10.Banyaknya jumlah konsumen dan pelaku usaha yang belum tersentuh pembinaan baik dari segi pemasaran, pengelolaan usaha dan upaya perlindungan konsumen PENUTUP dan pengamanan perdagangan.

\section{Simpulan}

Implementasi Good Governance dalam penyelenggaraan pemerintahan daerah di Kota Bukittinggi melalui dinas-dinas sebagai unit pelaksana teknis daerah dapat dilihat dari indikator-indikator pencapaian kinerja yang terdapat pada Rencana Strategis (Renstra), Rencana Kerja (Renja), serta Laporan Akuntabilitas Kinerja Instansi Pemerintah (LAKIP) pada masing-masing dinas. Berdasarkan Renstra, Renja, serta LAKIP pada masing-masing dinas, indikator-indikator pencapaian kinerja dapat dikatakan sudah dilaksanakan dengan baik. Pada DPRD Kota Bukittinggi sebagai lembaga legislatif daerah, implementasi good governance dapat dilihat dari pelaksanaan hak dan kewajiban,tugas, serta fungsi DPRD Kota Bukittinggi yang terdapat dalam Buku Profil dan Kinerja DPRD Kota Bukittinggi, dimana dalam pelaksanaannya berjalan dengan baik, namun masih terdapat kekurangan-kekurangan serta kegiatan-kegiatan yang belum dilaksanakan atau diwujudkan.

Kendala-kendala dalam implementasi good governance dalam penyelenggaraan pemerintahan daerah pada dinas-dinas sebagai unit pelaksana teknis daerah dapat dilihat dari kurang tercapainya target pencapaian indikator- indikator kinerja pada masing-masing dinas yang terdapat dalam Renstra, Renja, serta LAKIP pada masing-masing dinas. Kendala-kendala yang ada pada tiap-tiap dinas beragam, namun terdapat beberapa kesamaan kendala antar masing-masing dinas antara lain keterbatasan aturan-aturan yang belum sepenuhnya mengatur tentang kinerja pelayanan publik pada setiap instansi yang bersangkutan, keterbatasan SDM dari aparatur tiap-tiap dinas, serta sarana dan prasarana yang belum memadai untuk menunjang peningkatan pelayanan.

\section{Saran}

Untuk dinas-dinas sebagai unit pelaksana teknis daerah, perlunya peningkatan penyebaran informasi yang seluas-luasnya kepada masyarakat mengenai program kegiatan pembangunan yang dilakukan. Peningkatan kualitas SDM pada setiap dinas-dinas dengan cara pemilihan pendidikan aparatur yang sesuai dengan tugas pada masingmasing bidang pada dinas-dinas.

\section{DAFTAR PUSTAKA}

\section{Buku :}

Buku Profil dan Kinerja DPRD Kota Bukittinggi Masa Bhakti 2009-2014. Bukittinggi: Sekretariat DPRD Kota Bukittinggi

Dwiyanto, Agus. 2006. Mewujudkan Good Governance Melalui Pelayanan Publik. UGM Press: Yogyakarta.

Fauzan, Muhammad. 2006. Hukum Pemerintahan Daerah; Kajian Hubungan Keuangan Antara Pusat dan Daerah,Yogyakarta: UII Press.

Fauzi, Noer dan R.Yando Zakaria. 2000. Mensiasati Otonomi Daerah, Yogyakarta: 
Konsorsium Pembaruan Agraria bekerjasama dengan INSIST Press

Ibrahim, Johnny. 2011. Teori dan Metodologi Penelitian Hukum Normatif, Cetakan Keempat. Malang: Bayumedia Publishing

Juanda. 2008. Hukum Pemerintahan Daerah (Pasang Surut Hubungan Kewenangan Antara DPRD dan Kepala Daerah), Bandung: P.T. Alumni.

Laporan Akuntabilitas Kinerja Instansi Pemerintah. 2013. Bukittinggi: Dinas Koperasi, Perindustrian, dan Perdagangan.

Laporan Akuntabilitas Kinerja Instansi Pemerintah. 2013. Bukittinggi: Dinas Kependudukan dan Pencatatan Sipil.

Laporan Akuntabilitas Kinerja Instansi Pemerintah. 2013. Bukittinggi: Badan Pelayanan Perizinan Terpadu dan Penanaman Modal.

M. Hadjon, Philipus dkk. 2011. Hukum Administrasi dan Tindak Pidana Korupsi. Yogyakarta : Gadjah Mada University Press.

dkk.2012. Hukum administrasi dan Good Governance. Universitas Trisakti: Jakarta.

Rencana Strategis .2010-2015. Bukittinggi: Dinas Koperasi, Perindustrian dan Perdagangan.

Rencana Strategis .2010-2015. Bukittinggi: Dinas Kependudukan dan Pencatatan Sipil.

Rencana Strategis .2010-2015. Bukittinggi: Badan Pelayanan Perizinan terpadu dan Penanaman Modal.

Rencana Kerja. 2013. Bukittinggi : Dinas Koperasi, Perindustrian, dan Perdagangan

Rencana Kerja. 2013. Bukittinggi : Dinas Dinas Kependudukan dan Pencatatan Sipil.

Rencana Kerja. 2013. Bukittinggi : Badan Pelayanan Perizinan terpadu dan Penanaman Modal.

Rencana Kerja.2013. Bukittinggi : Sekretariat DPRD

Soekanto, Soejono.1988. Pengantar Penelitian Hukum, Jakarta: UI Press
Undang-Undang Dasar Negara Republik Indonesia tahun 1945.

Undang-Undang Nomor 32 Tahun 2004 tentang Pemerintahan Daerah.

Undang-Undang Nomor 28 Tahun 1999 tentang Penyelenggaran Negara yang Bersih dan Bebas Korupsi, Kolusi, dan Nepotisme.

Undang-Undang No.23 tahun 2006 tentang Administrasi Kependudukan.

Undang-undang No. 25 tahun 2009 tentang Pelayanan Publik.

Peraturan Daerah Kota Bukittinggi Nomor 12 Tahun 2008 tentang Pembentukan Organisasi dan Tata Kerja Dinas Daerah Kota Bukittinggi

Peraturan Walikota Bukittinggi Nomor 17 Tahun 2008 tentang Pembentukan Organisasi dan Tata Kerja Unit Pelaksana Teknis Dinas Kerajinan dan Industri pada Dinas Koperasi, Perindustrian dan Perdagangan Kota Bukittinggi.

\section{Peraturan Perundang-Undangan :}

